\title{
Analisis Rendemen dan Skrining Fitokimia Ekstrak Cacing Laut Eunice siciliensis
}

\author{
Andi Evi Erviani' ${ }^{1}$, Abdur Rahman Arif $^{2}$, Nurfahmiatunnisa ${ }^{1}$ \\ ${ }^{I}$ Departemen Biologi, Fakultas Matematika dan Ilmu Pengetahuan Alam \\ Universitas Hasanuddin \\ ${ }^{2}$ Departemen Kimia, Fakultas Matematika dan Ilmu Pengetahuan Alam \\ Universitas Hasanuddin \\ email:evierviani@gmail.com
}

\begin{abstract}
Sea worms have enormous potential to be used as alternative food ingredients because they have a fairly high protein content. The Research of the analysis yield and phytomomic compounds of Eunice Siciliensis marine worms has never been done. An effort to develop Eunice siciliensis sea worm-based alternative food ingredients is important to do phytochemical screening. This study aims to identify phytochemical compounds found in Eunice siciliensis marine worms and find out their benefits for health. This study was analyzed descriptively. The results showed that extract yield was $17.97 \%$ and Eunice siciliensis sea worm extract contained alkalaoid, flavonoids, saponins, triterpenoids / steroids, and tannins.
\end{abstract}

Kata kunci: Eunice siciliensis, yield, phytochemical screening, alternative food

\section{PENDAHULUAN}

Cacing laut Eunice siciliensis adalah cacing laut yang dapat kita temukan di Lombok dan Bima Nusa Tenggara Barat, Desa Parado Kec.parado . Selama ini cacing laut tersebut dikomsumsi oleh masyarakat karena kebiasaan turun temurun dan rasa gurih yang dimilikinya. Masyarakat Lombok dan Bima mengenal cacing laut tersebut sebagai makanan tradisional yang memiliki kandungan gizi yang tinggi. Namun penelitian ilmiah terkait kandungan senyawa fitokimia dari cacing laut tersebut belum pernah dilakukan. Sebagian besar masyarakat Lombok dan Bima belum mengetahui potensi-potensi lain yang dimiliki oleh cacing laut tersebut. Hal ini disebabkan kurangnya informasi tentang cacing laut E. siciliensis dan pemanfaatannya. Cacing laut memiliki kandungan protein yang tinggi namun belum dimanfaatkan secara optimal di Indonesia.

Cacing laut dari kelas Polychaeta bermanfaat sebagai pakan untuk induk udang (Rasidi,2013). Cacing laut (Polychaeta) banyak ditemukan pada permukaan laut pada musim kawin, yaitu setahun sekali baik pada bulan Maret atau April dan berkembangbiak secara ekstenal. Cacing laut yang hidup di daerah benthos menghasilkan bromophenol dan bromopyrrole. Cacing laut sebetulnya berpotensi untuk dikembangkan menjadi agen antibakteri karena penelitian dasarnya sudah ada. Jekti et al. (2008) berhasil mengungkap bahwa cacing laut Eunice siciliences mampu menghambat pertumbuban bakteri pada konsentrasi $100 \mu \mathrm{g} / \mathrm{ml}$. Cacing laut memiliki kandungan gizi yang cukup lengkap sehingga dapat dimanfaatkan sebagai bahan pangan alternatif. Kandungan gizi yang terdapat pada cacing laut yakni diketahui mengandung banyak protein (Liline., dkk. 2016), lemak, karbohidrat, abu, asam lemak dan 
asam amino, vitamin $\mathrm{A}, \mathrm{B} 1, \mathrm{~B} 6, \mathrm{~B} 12$, E, dan mineral $\mathrm{P}, \mathrm{I} 2, \mathrm{Ca}, \mathrm{Mg}, \mathrm{C}$ yang hampir setara dengan kandungan gizi pada ikan (Silaban 2012). Ekstrak cacing laut spesies Siphonosoma australe terbukti mengandung protein sebesar 56,35 \%, kadar abu 15,08 \%, kadar lemak 9,82 \% dan kadar karbohidrat sebesar 5,06 \% (Nurhikma, dkk, 2017). Terdapat juga berbagai macam asam amino pada cacing laut, di mana asam amino sangat penting dalam mendukung berbagai aktivitas fisiologis tubuh. Salah satu asam amino yang terdapat pada cacing laut adalah asam glutamat yang memiliki peran penting dalam metabolisme gula dan lemak, selain itu asam glutamat pada hewan ataupun tumbuhan dapat digunakan sebagai bahan pengobatan dalam mengatasi penyakit epilepsi, retardasi mental, distrofi otot, bisul, koma hipoglikemik, serta efek samping obat insulin untuk diabetes.

Skrining fitokimia merupakan uji kualitatif kandungan senyawa kimia dalam bagian tumbuhan, terutama kandungan metabolit sekunder yang di antaranya adalah flavonoid, alkaloid, saponin, tanin, terpenoid dan sebagainya. Skrining fitokimia harus memenuhi beberapa persyaratan antara lain sederhana, cepat, dapat dilakukan dengan peralatan yang minimal (Nirwana dkk, 2015; Nafisah dkk, 2014)

Salah satu cacing laut yang berpotensi untuk dibudidayakan di Lombok dan Bima Nusa Tenggara Barat adalah cacing laut Eunice sicilliensis, cacing laut ini banyak ditemukan di dearah pantai selatan Lombok dan bima (Soelistya dkk., 1993). Cacing ini hanya dikomsumsi oleh masayrakat. Potensi cacing laut ini belum dimanfaatkan dengan baik, karena kurangya informasi ilmiah mengenai kandungan senyawa fitokimia yang terdapat pada cacing laut ini.

Berdasarkan informasi di atas dan keterbatasan informasi mengenai senyawa fitokimia cacing laut Eunice siciliensis, maka dalam usaha pengembangan bahan pangan alternatif berbasis cacing laut Eunice siciliensis penting dilakukan skrining fitokimia terhadap ekstrak cacing laut Eunice siciliensis. Skrining fitokimia dilakukan terhadap ekstrak cacing laut Eunice siciliensis untuk mengetahui kandungan senyawa bioaktif pada Eunice siciliensis yang bermanfaat bagi kesehatan.

\section{METODE PENELITIAN}

Bahan-bahan yang digunakan adalah cacing laut Eunice siciliensis diperoleh dari daerah Lombok dan Bima Nusa Tenggara Barat . Bahan yang digunakan dalam ekstraksi adalah etanol absolut, sedangkan bahan yang digunakan dalam skrining fitokimia adalah reagen skrining fitokimia yang diperoleh dari Laboratorium Fitokimia Fakultas Farmasi Universitas Hasanuddin.

Alat-alat yang digunakan dalam penelitian ini adalah Blender,pisau,gunting, rotary vacuum evaporator Eyela SB-2100 (Tokyo, Jepang), labu Erlenmeyer, tabung reaksi, beaker glass, gelas ukur, aluminium foil, kertas saring. Alat alat yang digunakan dalam skrining fitokimia adalah chamber "CAMAG", plat KLT silika gel, pipa kapiler, dan glassware.

Prosedur kerja dalam penelitian ini adalah sebagai berikut:

\section{Ekstraksi Cacing Laut Eunice siciliensis}

Bahan baku yang digunakan adalah cacing Eunice siciliensis. Cacing Eunice siciliensis diambil sebanyak 1000 gram. Sampel selanjutnya dicuci menggunakan air mengalir. Sampel cacing yang sudah bersih kemudian dikeringanginkan, setelah kering kemudian dihaluskan menggunakan blander. Cacing Eunice siciliensis yang sudah dihaluskan tersebut digunakan untuk proses ekstraksi. Ekstraksi (Purwaningsih et al. 2008) Proses ekstraksi dilakukan dengan metode maserasi 24 jam. Lumatan halus cacing direndam menggunakan pelarut etanol dengan perbandingan 1:4 (b:v), dimaserasi selama 24 jam 
menggunakan orbital shaker 24 jam pada suhu ruang kemudian disaring menggunakan kertas saring Whatman no.42. Maserasi dilakukan sebanyak 3 x 24 jam. Filtrat yang dihasilkan dipisahkan pelarutnya menggunakan rotary vacuum evaporator pada suhu $40{ }^{\circ} \mathrm{C}$ selama 6 jam. Ekstrak yang dihasilkan kemudian ditimbang bobotnya.

\section{Analisis Rendemen dan Skrining Fitokimia}

Persentase rendemen ekstrak cacing Eunice siciliensis dapat dihitung dengan rumus: Rendemen $(\%)=$ Berat ekstrak (g)/ Berat sampel (g) x 100\%. Skrining fitokimia dilakukan untuk mengetahui komponen aktif pada suatu bahan. Analisis yang dilakukan terhadap ekstrak etanol meliputi pemeriksaan senyawa alkaloid, flavonoid, saponin, tanin, steroid dan triterpenoid. a) Alkaloid Sebanyak 0,05 g sampel dimasukkan ke dalam tabung reaksi lalu dilakukan penambahan $\mathrm{H}_{2} \mathrm{SO}_{4} 2 \mathrm{~N} 2$ tetes dan dikocok hingga benar-benar tercampur. Kemudian dituangkan dalam plat tetes dan ditetesi pereaksi Meyer dengan melihat endapan putih, pereaksi Wagner dengan melihat endapan coklat dan pereaksi 8 Dragendorff dengan endapan jingga, jika terdapat endapan tersebut maka sampel dikatakan positif. b) Flavonoid Sebanyak 0,05 g sampel ditambahkan serbuk Mg sebanyak 0,05 mg, setelah itu ditambahkan $0,2 \mathrm{~mL}$ amil alkohol dan $4 \mathrm{~mL}$ alkohol 70\%. Hasil uji positif bila larutan berwarna merah, kuning atau jingga pada lapisan amil alkohol. c) Saponin Uji saponin dapat dideteksi dengan uji busa dalam air panas. Sebanyak 0,05 g sampel diletakkan dalam tabung reaksi. Ditambahkan air panas kemudian tabung reaksi dikocok. Setelah tabung dikocok, dibiarkan selama 30 menit dan ditambahkan $\mathrm{HCl} 2 \mathrm{~N}$ sebanyak 1 tetes. Hasil uji positif saponin ditunjukkan dengan adanya busa yang stabil. d) Tanin Sebanyak 0,05 g sampel ditambah air panas, kemudian sampel tersebut ditetesi dengan $\mathrm{FeCl}_{3} 1 \%$ sebanyak 2 tetes. Hasil uji positif jika larutan berwarna biru tua atau hijau kehitaman. e) Steroid/ Triterpenoid Sebanyak 0,05 g sampel ditambah dengan $2 \mathrm{~mL}$ kloroform kemudian ditetesi dengan anhidrida asam asetat sebanyak 5 tetes. Setelah itu ditetesi dengan $\mathrm{H}_{2} \mathrm{SO}_{4} 2 \mathrm{~N}$ sebanyak 3 tetes. Hasil uji steroid positif bila warna larutan berubah menjadi biru, sedangkan hasil uji triterpenoid positif bila terbentuk warna merah kecoklatan pada lapisan permukaan sampel.

\section{Analisis Data}

Analisis yang dilakukan meliputi analisis rendemen ekstrak dan analisis skrining fitokimia. Data hasil pengamatan dilakukan analisis data secara deskriptif.

\section{HASIL DAN PEMBAHASAN}

\section{Analisis Rendemen}

Rendemen ekstrak dihitung berdasarkan perbandingan berat akhir (berat ekstrak yang dihasilkan setelah evaporasi) dengan berat awal (berat biomassa yang digunakan) dikalikan $100 \%$. Pembuatan ekstrak cacing laut (Eunice siciliensis), diawali dengan menimbang simplisia cacing laut yg sudah berbentuk serbuk, sebanyak 24 gram, kemudian dimaserasi dengan menggunakan etanol absolute sebanyak $150 \mathrm{ml}$ selama 1 x 24 jam. Ekstrak kemudian disaring dengan menggunakan kertas saring (filtrat 1), dan residu diekstrak kembali dengan etanol absolut sebanyak $150 \mathrm{ml}$ selama 1 x 24 jam, ekstrak kemudian disaring dengan menggunakan kertas saring (filtrat 2), dan residu diekstrak kembali dengan menggunakan etanol absolute sebanyak $150 \mathrm{ml}$ selama 1x 24 jam, kemudian ekstrak disaring kembali dengan menggunakan kertas saring (filtrat 3). Selanjutnya filtrat 1 , filtrat 2 , dan filtrat 3 dikumpulkan dalam satu wadah. Filtrat selanjutnya diuapkan dengan menggunakan vacuum evaporator 
hingga volumenya berkurang dan menghasilkan ekstrak cacing laut sebanyak, 4, 313 gram. Hasil rendemen ekstrak dengan menggunakan pelarut etanol adalah 17,972 \% dengan waktu ekstraksi selama 60 menit. Rendemen yang cukup tinggi ini dapat dipengaruhi oleh pelarut yang digunakan, pelarut etanol yang digunakan memiliki sifat kepolaran yang sama dengan sebagian besar komponen yang terdapat pada biomassa sel Eunice siciliensis. Beberapa senyawa fitokimia yang terlarut dalam pelarut polar sehingga senyawa yang terekstrak dengan pelarut etanol ini cukup banyak dan menghasilkan rendemen yang cukup tinggi. Hal ini ditunjukkan oleh ekstrak yang berwarna cokelat pekat.

\section{Skrining Fitokimia}

Senyawa fitokimia merupakan senyawa golongan metabolit sekunder dalam makhluk hidup yang memiliki fungsi tertentu bagi manusia. Senyawa fitokimia merupakan senyawa golongan metabolit sekunder dalam tumbuhanataupun hewan yang memiliki fungsi tertentu bagi manusia. Untuk mengetahui senyawa fitokimia tersebut, pada penelitian ini dilakukan identifikasi terhadap lima jenis senyawa fitokimia yang diperkirakan terdapat pada ekstrak cacing laut Eunice siciliensis Senyawa fitokimia tersebut adalah senyawa golongan alkaloid, flavonoid, antrakuinon, glikosida steroid, glikosida flavonoid, dan saponin. Hasil identifikasi senyawa fitokimia pada ekstrak cacing laut Eunice siciliensis sebagaimana pada Tabel 1.

Tabel 1. Hasil skrining fitokimia ekstrak Perinereis aibuhitensis

\begin{tabular}{|l|l|l|}
\hline Uji Fitokimia & Hasil Positif Menurut Pustaka & Hasil \\
\hline Alkaloid & Terbentuk endapan jingga (Pereaksi Dragendorff) & + \\
\hline Flavonoid & Terjadi Perubahan warna dari tabung kontrol & + \\
\hline Saponin & Ada busa yang bertahan dalam 10 menit setinggi $10 \mathrm{~cm}$ & + \\
\hline Triterpenoid/Steroid & Cincin kecokelatan atau violet & + \\
\hline Tanin & Terbentuk warna biru tua atau hitam kehijauan & + \\
\hline \multicolumn{2}{|c|}{ Keterangan $:+:$ terkandung senyawa }
\end{tabular}

Hasil skrining fitokimia menunjukkan bahwa ekstrak cacing laut Eunice siciliensis mengandung alkaloid, flavonoid, saponin, triterpenoid/steroid dan tanin. Alkaloid dapat dideteksi dengan cara pengendapan menggunakan pereaksi Mayer, Wagner, dan Dragendorff (Harborne 1987). Senyawa golongan alkaloid digunakan untuk pengobatan seperti antimalaria, antioksidan, obat asma serta memiliki efek sebagai antihiperglikemik (Tiong et al. 2013). Menurut Firdaus et al. (2004), alkaloid yang memiliki khasiat sebagai antihiperglikemik antara lain leurosine, leurosine sulfat, vindoline, dan vindolinine.

Senyawa bahan aktif yang lain adalah flavonoid yang merupakan senyawa polar yang mempunyai gugus hidroksil atau gula, sehingga dapat larut dalam pelarut polar seperti etanol, metanol, butanol, aseton, dimetilsulfoksida, dan air (Harborne 1987). Menurut Dheer dan Bhatnagar (2010), flavonoid merupakan zat yang mampu meregenerasi sel beta pankreas dan membantu merangsang sekresi insulin. Hal tersebut sesuai dengan penelitian yang dilakukan Brahmachari (2011) yang menyatakan bahwa flavonoid memiliki efek hipoglikemik dengan mengurangi penyerapan glukosa dan mengatur aktivitas ekspresi enzim yang terlibat dalam metabolisme karbohidrat.

Senyawa bahan aktif berikutnya adalah saponin, Firdous et al. (2009) menyatakan bahwa saponin merupakan senyawa aktif yang memiliki permukaan kuat dan dapat menimbulkan busa pada saat dikocok dengan air. Strukturnya terdiri dari aglycone (triterpene atau steroid) dan gugus glukosa. 
Yoshikawa et al. (2005), menyatakan bahwa saponin memiliki banyak fungsi biologi dan farmakologi diantaranya sebagai hemolisa, kardiotonik, hipoglikemik, hipokolesterolemik, modulator imun, hepatoproteksi, antioksidan, dan antikardiogenik. Saponin berfungsi sebagai antihiperglikemik dengan mekanisme mencegah pengosongan lambung dan mencegah peningkatan uptake glukosa pada brush border membran di intestinal.

Steroid merupakan senyawa yang secara umum memiliki struktur siklik dan mempunyai gugus hidroksil (Harbone 1987). Senyawa steroid fukosterol yang diisolasi dari sumber daya hayati laut bersifat non toksik dan mempunyai khasiat menurunkan kolesterol dalam darah dan mendorong aktivitas antidiabetes. Mukhriani (2014) menyatakan bahwa senyawa steroid dapat digunakan sebagai bahan dasar pembuatan obat. . Nurulita et al. (2008) menyebutkan senyawa steroid merupakan komponen aktif yang telah digunakan untuk pengobatan penyakit diabetes, gangguan menstruasi, sebagai antibakteri dan antivirus.

Perbedaan hasil yang diperoleh menurut Iswantini et al. (2011) diduga karena adanya perbedaan kondisi lingkungan hidup. Kondisi lingkungan hidup yang berbeda dapat menyebabkan perbedaan jenis dan jumlah dari metabolit sekunder yang terkandung dalam suatu bahan. Widarta et al. (2013) menyebutkan perbedaan jenis dan tingkat kepolaran pelarut dapat menghasilkan rendemen ekstrak dan komponen bioaktif yang berbeda. Sompong et al. (2010) menyatakan bahwa perbedaan spesies dan tempat tumbuh menghasilkan komponen bioaktif yang berbeda.

\section{KESIMPULAN}

Pada penelitian ini hasil ekstraksi dengan menggunakan pelarut etanol absolute diperoleh rendemen ekstrak sebesar 17,972\%. Hasil skrining fitokimia dengan metode Kromatografi Lapis Tipis menunjukkan bahwa ekstrak cacing laut dengan menggunakan pelarut etanol absolut mengandung lima senyawa fitokimia yaitu senyawa alkaloid, flavonoid, saponin, triterpenoid/steroid, dan tanin yang ditunjukkan dengan timbulnya noda warna spesifik pada silika gel hasil KLT.

\section{DAFTAR PUSTAKA}

Brahmachari G. 2011. Bio-flavonoids with promising antidiabetic potentials: acritical survey. Research Signpost. 661(2): 187-212.

Dheer R, Bhatnagar P. 2010. A study of the antidiabetic activity of Barleriaprionitis Linn. Indian Journal of Pharmacology. 42(2): 1-5.

Firdaus RT, Suhartono E, Qamariah N. 2004. Pemodelan reaksi glikolsilasi dan peran infus daun tapak dara (Catharantus roseus [L] G. Don) sebagai penghambat kerusakan protein. Berkala Ilmu Kedokteran. 36(1): 1-6.

Firdous M, Koneri R, Sarvaraidu CH, Shubhapriya KH. 2009. NIDDM antidiabetic activity of saponins of Momordica cymbalaria in streptozotocin-nicotinamide NIDDM mice. Journal of Clinical and Diagnosis Research. 3: 1460-1465.

Harborne JB. 1987. Metode Fitokimia. Edisi ke-2. Padmawinata K, Soediro I, penerjemah. Bandung (ID): Institut Teknologi Bandung. Terjemahan dari: Phytochemical Iswantini D, Silitonga RF, Martatilofa E, Darusman LK. 2011. Zingiber cassumunar, Guazuma ulmifolia, and Murray paniculata extracts as antiobesity: in vitro inhibitory effect on pancreatic lipase activity. Hayati Journal of Bioscience. 18 (1): 6-10. 
Iswantini D, Silitonga RF, Martatilofa E, Darusman LK. 2011. Zingiber cassumunar, Guazuma ulmifolia, and Murray paniculata extracts as antiobesity: in vitro inhibitory effect on pancreatic lipase activity. Hayati Journal of Bioscience. 18 (1): 6-10.

Jekti DSD, Purwoko AA \& Muttaqin Z. 2008. Nyale Cacing Laut Sebagai Bahan Antibakteri. Jurnal Ilmu Dasar 9 (1): 120-121.

Liline, S. et al., 2016. The Identification Of Laor Worms (Polychaeta) In Marine Areas Of Ambon Island, Mollucas Province,Indonesia Based On 16s Rrna Gene Sequence. Journal of ChemTech Research. 9(6): 307-315.

Mukhriani. 2014. Ekstraksi, pemisahan senyawa, dan identifikasi senyawa aktif. Jurnal Kesehatan. 7(2): 361-367.

Nafisah M, Tukiran, Suyatno, Hidayati N. 2014. Uji Skrining Fitokimia Pada Ekstrak Heksan, Kloroform dan Metanol dari Tanaman Patikan Kebo (Euphorbiae hirtae). Prosiding Seminar Nasional Kimia. ISBN : 978-602-0951-00-3.

Nirwana AP, Astirin OP, Widiyani T. 2015. Skrining Fitokimia Ektrak Etanol Daun Benalu Kersen (Dendrophtoe pentandra L.Miq). El-Vivo, Volume 3, Nomor 2: 9-15

Nurhikma, Nurhayati T, Purwaningsih S. 2017. Kandungan Asam Amino, Asam Lemak, dan Mineral Cacing Laut Dari Sulawesi Tenggara. JPHPI, Volume 20, Nomor 1.

Nurulita Y, Haryanto D, Andreanus AS. 2008. Penapisan aktivitas dan senyawa antidiabetes ekstrak air daun dandang gendis (Clinacanthus nutans). Jurnal Natur Indonesia. 10(2): 98-103.

Purwaningsih S, Rimbawan, Priosoeryanto BP. 2008. Ekstraksi komponen aktif sebagai antikanker pada sel lestari keong matah merah (Cerithidea obtusa). Jurnal Ilmu-Ilmu Perairan dan Perikanan Indonesia. 15(2): 103-108

Rasidi. 2013. Mengenal Jenis-Jenis Cacing Laut dan Peluang Budidayanya untuk Penyediaan Pakan Alami di Pembenihan Udang. Media Akuakultur 8(1): 58.

Silaban B br. 2012. Profil Nutrisi Sipuncula(Cacing Kacang); Biota Laut yang Kontrovertif di Pulau Nusalaut, Maluku Tengah. Ambon: Laporan Hasil Penelitian Dosen Pemula. Dibiayai dengan PNBP Lembaga Penelitian Universitas Pattimura

Sompong R, Siebenhandl ES, Linsberger MG, Berghofer E. 2011. Physicochemical and antioxidative properties of red and black rice varieties from Thailand, China and Sri Lanka. Journal of Food Chemistry. 124: 132-140.

Soelistya, dkk., 1993. Jenis-jenis Polychaeta Di Pulau Lombok dan Peristiwa Baunyale.Jurnal Ilmuilmu Perairan dan Perikanan Indonesia . 1(1): 21-32

Tiong, S,H, et al., 2013. Antidiabetic and antioxidant properties of alkaloids from Catharanthus roseus

(L.) G. Don. Department of Chemistry, Faculty of Science, University of Malaya, Kuala Lumpur, Malaysia.18(8). 70-84.

Widarta, I, W, R., Nocianitri, K, A., Sari, L,P,I,P. 2013. Ekstraksi Komponen Bioaktif Bekatul Beras Lokal dengan Beberapa Pelarut. Jurnal Aplikasi Teknologi Pangan.Vol 2 No 2: 75-79.

Yoshikawa M, Toshio M, Ning L, Akifumi N, Zian L, Hisashi M. 2005. Bioactive saponins and glycosides. XXIII.1) triterpene saponins with gastroprotective effect from the seeds of Camellia sinensis teasaponins E3, E4, E5, E6, and E7. Chemical and Pharmaceutical Bulletin. 53(12):1559-1564. 